\title{
Kredietcrisis en de jaarrekening van Nederlandse ondernemingen
}

\section{Robin Litjens en Ruud Vergoossen}

SAMENVATTING In dit artikel wordt verslag gedaan van een onderzoek naar de effecten van de kredietcrisis zoals die naar voren komen in de jaarrekening 2008 van in totaal 99 Nederlandse beursfondsen die niet behoren tot de financiële sector. Uit het onderzoek blijkt dat het aantal ondernemingen dat niet meer voldoet aan kredietvoorwaarden die zij met banken zijn overeengekomen, belangrijk is toegenomen. Verder laat het onderzoek zien dat de beurswaarde van veel ondernemingen ultimo 2008 ver beneden hun boekwaarde is komen te liggen en dat de afboekingen op de bezittingen van ondernemingen in het boekjaar 2008 zijn gestegen. Ook is in dat boekjaar in vergelijking met het boekjaar daarvoor een toename van de reorganisatiekosten waar te nemen. Dat deze effecten zichtbaar zijn in de jaarrekening betekent dat de reële gevolgen van de kredietcrisis door het management (veranderde inschattingen omtrent de toekomst) zijn doorvertaald in de jaarrekening. Daarbij moet echter rekening worden gehouden met een toegenomen invloed van het management op de weergave van de economische realiteit.

\section{RELEVANTIE VOOR DE PRAKTIJK IFRS wordt gekenmerkt door het decision usefullness-concept. Dit betekent dat de informatie die is opgenomen in de jaarrekening nuttig moet zijn voor de gebruiker bij het nemen van economische beslissingen. Het} weergeven van de economische realiteit is daarbij - ook in crisistijd - een belangrijk uitgangspunt. Aan de hand van drie thema's (leningconvenanten, bijzondere waardeverminderingen en reorganisatievoorzieningen) is onderzocht in welke mate een crisis invloed heeft op de weergave van de economische realiteit en daarmee het mogelijke gebruiksnut van de jaarrekening. Voor regelgevers kunnen de resultaten van belang zijn bij het bepalen welke mate van detail in de regelgeving noodzakelijk is en om het gedragselement van regelgeving te evalueren.

\section{Introductie}

'The problem with investment bank balance sheets is that on the left side nothing is right and on the right side nothing is left.' ${ }^{1}$ Deze quote geeft aan hoe gedacht wordt over de balansen van banken, maar bergt ook kritiek in zich op de externe financiële verslaggeving in het algemeen. Veel kritiek is er met name op de waardering tegen reële waarde onder IFRS en US GAAP en het buiten de balans houden van bepaalde financiële constructies door banken en verzekeringsmaatschappijen. ${ }^{2}$ Daarentegen is aan de effecten van de kredietcrisis zoals die tot uiting komen in de externe verslaggeving van niet-financiële instellingen - dat wil zeggen de ondernemingen in de reële economie - relatief weinig aandacht besteed. Hierna beschrijven wij hoe wij deze effecten aan de hand van 99, aan Euronext Amsterdam genoteerde ondernemingen zullen onderzoeken. ${ }^{3}$

De jaarrekening is een gecombineerde weergave van de economische realiteit en de perceptie van het management aangaande die economische realiteit. Daarbij wordt de economische realiteit beïnvloed door algemeen economische en bedrijfsspecifieke ontwikkelingen. In 2008 is er sprake van een kredietcrisis die gepaard gaat met de grootste economische terugval sinds de jaren dertig van de vorige eeuw. Deze crisis kent enkele specifieke algemeen economische effecten (het stilvallen van geldstromen in de economie, omvangrijke en scherpe vraaguitval in specifieke sectoren en een sterk oplopende werkeloosheid) waarvan het de verwachting is dat zij in de jaarrekening 2008 de economische realiteit en de perceptie van het management domineren. Dit stelt ons in staat om op macroniveau hypothesen te formuleren over op welke wijze algemeen economische effecten de jaarrekening 2008 domineren, om vervolgens te analyseren wat de invloed van het management is op de weergave van de economische realiteit.

Belangrijke gevolgen van de kredietcrisis voor de reële economie die wij in het jaarrekeningonderzoek zullen betrekken, zijn:

- door het stilvallen van geldstromen in de economie zijn financieringsproblemen ontstaan;

- door een scherpe terugval in de vraag komt de winstgevendheid van ondernemingen onder druk te staan;

- er is sprake van een sterk oplopende werkeloosheid.

Wij zullen ons in dit artikel derhalve focussen op de volgende onderwerpen in de jaarrekening (met tussen haakjes de relevante IFRS): 
- betalingsachterstanden op kredieten, de naleving van de kredietvoorwaarden (convenanten) en de verkrijging van krediet (IFRS 7);

- het doorvoeren van bijzondere waardeverminderingen (IAS 36);

- reorganisaties en het tijdstip van het vormen van reorganisatievoorzieningen (IAS 37).

\section{Dataverzameling, onderzoekspopulatie en beperkingen}

Object van onderzoek zijn de jaarrekeningen over het boekjaar 2008. Om een benchmark te creëren van een economisch stabiele periode waarmee we de effecten blijkens de jaarrekening 2008 kunnen vergelijken, is voor dezelfde ondernemingen een referentieperiode van drie jaar genomen, dat wil zeggen de boekjaren 2005-2007. De data uit de primaire jaarrekeningoverzichten (balans, resultatenrekening, kasstroomoverzicht) en marktdata zijn afkomstig van Mint Global. Sommige benodigde data zijn alleen in toelichtingen op de primaire overzichten beschikbaar en zijn daarom rechtstreeks aan de jaarrekeningen ontleend. Daar waar data rechtstreeks aan de jaarrekeningen zijn ontleend, is alleen boekjaar 2007 als referentieperiode genomen.

De onderzoekspopulatie van 99 ondernemingen verdeeld over diverse branches heeft niet altijd voldoende omvang om op brancheniveau betrouwbare resultaten te trekken. Dit betekent dat conclusies op het niveau van individuele branches indicatief zijn. Conclusies aangaande de totale populatie achten wij wel representatief.

Daarnaast worden de resultaten in beginsel beïnvloed door verschillen in grootte van ondernemingen. ${ }^{4}$ Dit is ondervangen door de resultaten daar waar nodig te schalen om de invloed van de omvang van ondernemingen te beperken. ${ }^{5}$

In het navolgende zullen wij de onderzoeksresultaten bespreken ten aanzien van de hiervoor genoemde onderwerpen: naleving convenanten en krediet (paragraaf 2), bijzondere waardeverminderingen en toekomstige winstgevendheid (paragraaf 3) en vorming van reorganisatievoorzieningen (paragraaf 4). De paragrafen 2 tot en met 4 vallen elk uiteen in drie onderdelen: (i) hypothesevorming van het effect in de jaarrekening, (ii) het effect blijkens de jaarrekening en (iii) de invloed van het management op de weergave van de economische realiteit. Wij sluiten af met enkele concluderende opmerkingen in paragraaf 5 .

\section{Naleving convenanten en krediet}

\subsection{Hypothesevorming}

Om het risico van verzuim of niet-nakomen van contractafspraken bij kredieten te mitigeren, vragen kredietinstellingen aan ondernemingen vaak om zekerheden op activa te stellen (hypothecair krediet) of spreken zij convenanten af. Veelvoorkomende convenanten in kredietovereenkomsten hebben betrekking op:

- de solvabiliteit (SOLV):

dat is de verhouding tussen eigen en vreemd vermogen en is een indicatie in hoeverre een onderneming in staat is om aan de verplichtingen te voldoen met behulp van alle activa. Solvabiliteit is voor een financier met name een 'bescherming' bij faillissement. Uit de convenanten (tabel 1 , kolom 'convenanten in bestaande leningsovereenkomsten', subkolom 'SOLV') blijkt dat gemiddeld een minimale solvabiliteit van 0,26 wordt gehanteerd door banken;

- de interest coverage ratio (ICR): dat is de EBITDA(Earnings Before Interest, Taxes, Depreciation and Amortisation) gedeeld door de rentelasten, met andere woorden: hoe vaak verdient een onderneming haar rentelasten terug? Dit is een veiligheidsmarge voor een bank zodat een onderneming naar verwachting blijvend aan haar renteverplichtingen kan blijven voldoen. De normen in kredietovereenkomsten zijn minima, dat wil zeggen dat als ICR $=3$ dat EBITDA ten minste drie keer zo hoog moet zijn als de rentelasten;

- de leverage ratio (LR):

dat is de totale schuld gedeeld door de EBITDA, met andere woorden: binnen hoeveel jaar kan een onderneming haar krediet aflossen met EBITDA? Dit is een veiligheidsmarge voor een bank zodat een onderneming naar verwachting blijvend aan haar aflossingsverplichtingen kan blijven voldoen. De normen in kredietovereenkomsten zijn maxima en meestal wordt een norm van drie aangehouden. Dus het totaal van het uitstaand krediet op balansdatum mag maximaal drie keer EBITDA zijn.

Voorgaande convenanten herbergen ratio's ten aanzien van de balans (solvabiliteit) alsmede het activiteitenniveau en de winstgevendheid van de onderneming. Door de scherpe vraaguitval als gevolg van de kredietcrisis komen resultaten en kasstromen onder druk te staan. Dit leidt tot de volgende hypothesen:

H1a: Het aantal ondernemingen dat betalingsachterstanden oploopt, is in 2008, vergeleken met de economisch stabiele referentieperiode, toegenomen.

H1b: Het aantal ondernemingen dat niet voldoet aan leningconvenanten is in 2008, vergeleken met de economisch stabiele referentieperiode, toegenomen.

Binnen de financiële verslaggeving is er een onderzoeksstroming die resultaatsturing probeert te identificeren aan de hand van discontinuïteiten in de verdeling van het winstcijfer (Burgstahler en Dichev, 1997; Durtschi en Easton, 2005 en 2009; Jacob en Jorgenson, 2007) en onderzoeken die kijken naar het afronden van cijfers 
(bijvoorbeeld Das en Zhang, 2001). In deze onderzoeken wordt verondersteld dat er sprake is van een drempel of grens - met economische gevolgen - die leidt tot een prikkel bij het management om op een bepaalde manier te rapporteren. Omdat het gaat om beperkte afwijkingen tussen de werkelijk gerapporteerde cijfers en de drempel of grens, is de (weerlegbare) aanname dat het management dit doet met behulp van verslaggevingskeuzen (zoals stelselwijzigingen en schattingswijzigingen) en de beïnvloeding niet geschiedt door middel van (de aanpassing van) reële transacties.

Vaak staat in een kredietovereenkomst dat wanneer aan een of meer convenanten (op balansdatum) niet meer wordt voldaan, dit de bank in staat stelt om versnelde terugbetaling van het krediet te eisen of - als gevolg van toegenomen risico - een kredietrisico-opslag op de rente te zetten. Het niet-voldoen aan een convenant heeft dus economische consequenties en is daarmee een relevante drempel of grens voor het management. Een belangrijk gevolg van de kredietcrisis is dat banken moeilijker krediet verstrekken en dat bankkrediet duurder is geworden. Dit blijkt onder meer uit het feit dat banken meer risico's op de balans houden, waardoor minder uitgeleend kan worden en de rentemarges zullen stijgen. ${ }^{6}$ Daarnaast is de converteerbare obligatielening weer terug van weggeweest $(50 \%$ meer uitgiften in 2009 in Europa, zie Eshuis en Wolzak 2009). Een converteerbare obligatielening wordt gezien als oplossing wanneer het te duur is (banken vragen relatief hoge risicopremies) om vreemd vermogen aan te trekken; in ruil voor het optierecht wordt een lagere rente betaald. Derhalve zal kredietverstrekking bij een andere bank in geval van vervroegd terugbetalen moeilijker worden. Bovendien zullen banken minder snel bij overtreding van convenanten een waiver verstrekken. Resumerend is het de verwachting dat de consequenties van het niet-voldoen aan convenanten in 2008 groter zullen zijn. Dit leidt tot een grotere prikkel bij het management om invloed uit te oefenen op de weergave van de economische realiteit. Wij verwachten dat dit - analoog aan het onderzoek inzake resultaatsturing - tot uitdrukking zal komen in een grote discontinuïteit in de verdeling van het wel/niet-voldoen aan convenanten. Er zullen relatief meer ondernemingen zijn die net wel aan de convenanten voldoen.

Op basis daarvan formuleren wij de volgende hypothese:

H1c: De invloed van het management op de weergave van de economische realiteit is in 2008, vergeleken met de economisch stabiele referentieperiode, toegenomen.

\subsection{Effect blijkens de jaarrekening}

IFRS 7.18 stelt dat voor aangegane kredieten het volgende toegelicht dient te worden:
- wanneer een onderneming gedurende het boekjaar contractuele bepalingen ten aanzien van rente of aflossingen niet nakomt (betalingsachterstanden);

- de boekwaarde van de leningen met betrekking tot welke de entiteit in gebreke is gebleven; en

- of het in gebreke zijn is opgeheven of de contractvoorwaarden zijn aangepast vóór de datum van het opmaken van de jaarrekening.

Wij hebben in geen enkele jaarrekening over het boekjaar 2008 een melding aangetroffen dat een onderneming achterstanden heeft op haar rente- en aflossingsverplichtingen. Op grond daarvan kunnen wij hypothese ra niet bevestigen. Een mogelijke verklaring is dat het effect van vraaguitval vertraagd doorwerkt in de liquiditeitspositie of dat ondernemingen voorrang verlenen aan het voldoen aan rente- en aflossingsverplichtingen.

Daarnaast stelt IFRS 7.19 dat indien er zich andere schendingen (anders dan betalingsachterstanden) van bepalingen van de kredietovereenkomst hebben voorgedaan indien deze schendingen de financier in staat stellen versnelde aflossing te eisen - dan moet een onderneming hetzelfde toelichten als hetgeen onder IFRS 7.18 is vereist. Bij andere schendingen moet bijvoorbeeld worden gedacht aan het niet-nakomen van convenanten. In totaal meldt $59 \%$ van de onderzochte ondernemingen in 2008 kredieten met convenanten te hebben (tabel 1, kolom 'ondernemingen met convenanten') ten opzichte van $58 \%$ in 2007 . Uit tabel 1 kan worden afgelezen dat $14 \%$ van de ondernemingen in de jaarrekening 2008 aangeeft ultimo 2008 niet (meer) te voldoen aan een of meer convenanten ten opzichte van $2 \%$ ultimo 2007 (tabel 1, kolom 'overtredingen convenanten'). Dit is een verzevenvoudiging in één jaar tijd. Dit betekent dat wij hypothese $1 \mathrm{~b}$ inzake het nietvoldoen aan leningconvenanten kunnen bevestigen. Het niet-voldoen aan convenanten beperkt zich overigens tot enkele branches (industrie, consumentenservices en technologie). Doordat de rente en aflossingen veelal contractueel vaststaan, zorgt een daling in EBITDA ervoor dat ondernemingen niet meer voldoen aan de interest coverage ratio en de leverage ratio. Het is voornamelijk de schending van deze convenanten die geleid heeft tot een verzevenvoudiging van het aantal schendingen.

\subsection{Invloed management op weergave economische realiteit}

\section{Bestaande kredieten}

In de economisch stabiele periode (2005-2007) heeft 3\% van de ondernemingen een onder/overschrijding van minder dan $10 \%$ van de convenanten blijkens de ratio's bepaald op basis van de jaarrekening (tabel 1, kolom 'invloed van het management'). Dit is te verwachten als het management niet of slechts beperkt invloed uitoefent 


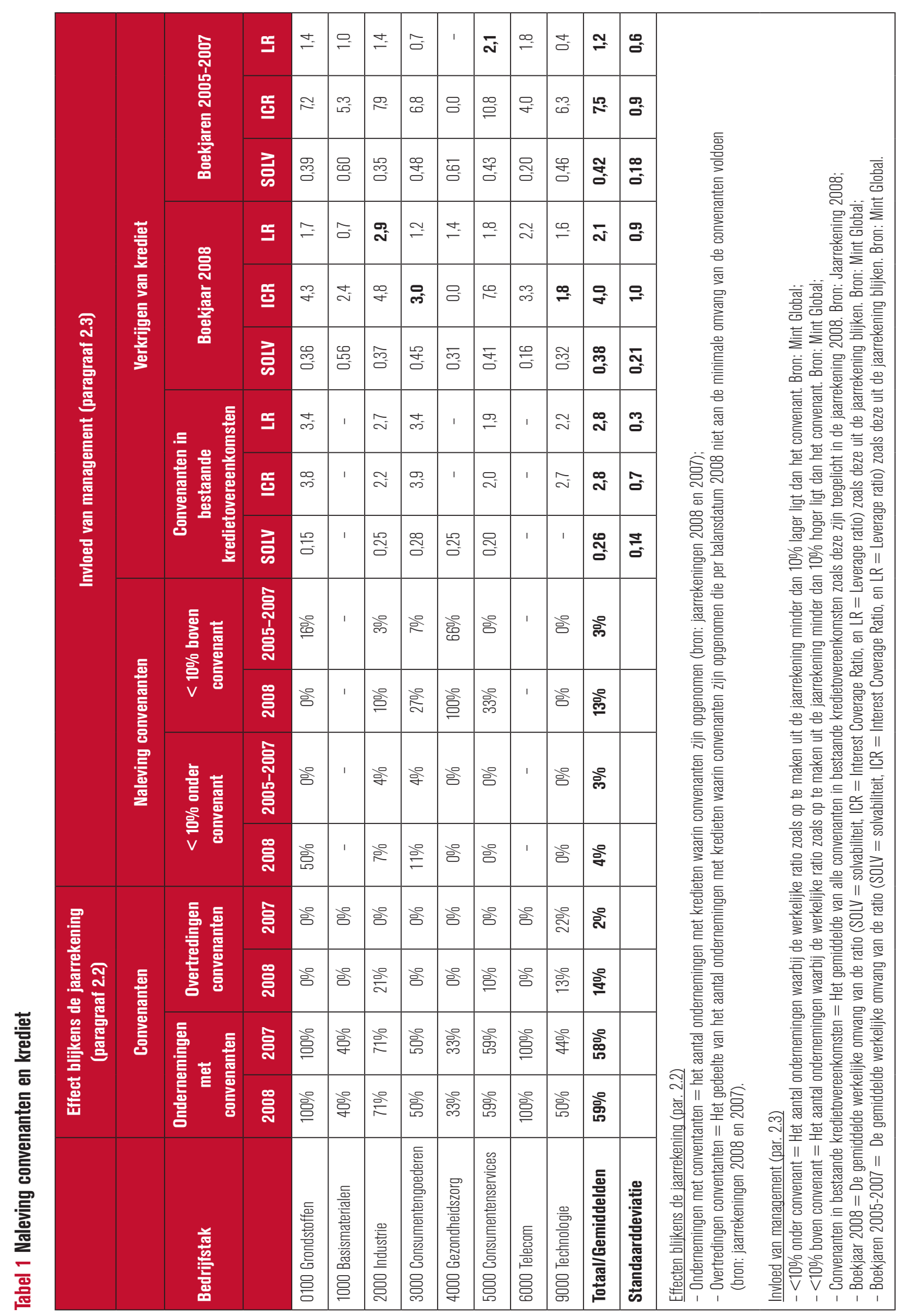


op weergave van de economische realiteit. In 2008 is de onderschrijding - dus het net niet voldoen aan de convenanten - nagenoeg hetzelfde (4\%). Echter, de overschrijding - dus het net wel voldoen aan de convenanten - is toegenomen van $3 \%$ naar $13 \%$; meer dan een verviervoudiging. Deze discontinuïteit in de verdeling is vergelijkbaar met de resultaten van Burgstahler en Dichev (1997).

Hoewel we, gezien het aantal waarnemingen, voorzichtig moeten zijn met het trekken van conclusies, lijkt er sprake te zijn van een toegenomen invloed van het management op de weergave van de economische realiteit als gevolg van de onder hypothese 1c toegenomen consequenties van het niet-voldoen aan convenanten. Het gevolg kan zijn dat de onder 2.2 beschreven verzevenvoudiging van de overtreding van convenanten blijkens de jaarrekeningen te laag is en in werkelijkheid hoger zou moeten zijn.

\section{Nieuwe kredieten}

Hoe zit het met de invloed van het management op het weergeven van de economische realiteit in het kader van het verkrijgen van nieuwe kredieten? Als gesteld kan worden dat de convenanten in bestaande kredietovereenkomsten 'rendementseisen' zijn die banken hanteren bij het verstrekken van nieuw krediet (en opnemen in af te sluiten kredietovereenkomsten), dan kunnen we die vergelijken met de werkelijke verhoudingsgetallen die te berekenen zijn op basis van de jaarrekeningen. ${ }^{8}$ Wanneer we per branche de convenanten in de contracten (tabel 1 , kolom 'convenanten in bestaande kredietovereenkomsten') vergelijken met de berekende werkelijke verhoudingsgetallen gedurende de referentieperiode (2005-2007), dan zou alléén de branche consumentenservices niet voldoen aan de leverage ratio. Voor 2008 geldt dit voor drie verhoudingsgetallen in twee branches (leverage ratio voor industrie en interest coverage ratio voor consumentengoederen en technologie). De risico's lijken zich aldus te beperken tot enkele branches. Enige voorzichtigheid is hier echter geboden. De standaarddeviatie van de verhoudingsgetallen van de convenanten zoals die blijken uit de jaarrekeningen in de referentieperiode 2005-2007, is hoger (tabel 1, kolom 'boekjaren 2005-2007') dan de standaarddeviatie van de convenanten zoals die blijken uit de kredietovereenkomsten (tabel 1, kolom 'convenanten in bestaande kredietovereenkomsten'). Dit duidt op een meer gediversifieerd risico bij ondernemingen waar banken zich niet op aanpassen; zij blijven een eenduidigere 'rendementseis' hanteren. Bovendien is de standaarddeviatie voor alle verhoudingsgetallen in 2008 toegenomen ten opzichte van de referentieperiode. Dit betekent dat in 2008 het risico verder gediversifieerd is, waardoor een beperktere groep ondernemingen kredietmogelijkheden heeft. Hoewel de invloed van het management op de economische realiteit in de jaarrekening ten behoeve van het verkrijgen van nieuw krediet niet direct meetbaar is, lijkt de prikkel voor het management om de economische realiteit te beïnvloeden ter verkrijging van nieuw krediet, beperkt.

\section{Bijzondere waardeverminderingen}

\subsection{Hypothesevorming}

Tijdens de kredietcrisis heeft zich een bijzonder fenomeen gemanifesteerd ten aanzien van de verhouding tussen de beurswaarde en de boekwaarde van de in het onderzoek betrokken ondernemingen (zie Vergoossen en Litjens. 2009). Uit ons onderzoek blijkt namelijk dat op balansdatum (31 december 2008) 33\% van de ondernemingen een beurswaarde heeft die lager is dan de boekwaarde $(\mathrm{PtB}<1)$ ten opzichte van gemiddeld $4 \%$ gedurende de referentieperiode (tabel 2, kolom 'economisch effect').

Dat de beurswaarde van een onderneming niet gelijk is aan de boekwaarde is een geaccepteerd verschijnsel, maar onder normale omstandigheden is de beurswaarde meestal (vele malen) hoger dan de boekwaarde. In de wetenschap staat dit verschijnsel bekend als conservatisme en zit opgesloten in de verslaggevingsregels. ${ }^{9}$ Ten eerste worden niet alle bedrijfsmiddelen in de balans opgenomen. Daarbij kan worden gedacht aan knowhow, merkenrechten, patenten, klantentrouw en andere immateriële bedrijfsaspecten. Ten tweede worden activa die wél in de balans worden opgenomen vaak gewaardeerd op historische kostprijzen (minus afschrijvingen en bijzondere waardeverminderingen). Ten slotte worden voorzieningen getroffen wanneer er naar verwachting een uitstroom van middelen noodzakelijk zal zijn. De beurswaarde is afhankelijk van de hoogte van de andelenkoers die wordt bepaald door de inschattingen die de markt maakt van de winstcapaciteit van de onderneming. De markt wordt geacht - al dan niet op basis van de jaarrekening - dit conservatisme te absorberen in de aandelenkoers.

Als de boekwaarde van een onderneming onder de beurswaarde is gedaald, dan is dit onder IFRS (IAS 36.12d) een indicatie dat er mogelijk sprake is van een bijzondere waardevermindering op vaste activa. IFRS bepaalt dan ook dat het management een toets op bijzondere waardevermindering moet doen om de realiseerbare waarde van de vaste activa vast te stellen. ${ }^{10}$

Bij de ondernemingen met een $\mathrm{PtB}<1$ is het aantal bijzondere waardeverminderingen $(70 \%)$ groter dan die van de gehele populatie $(57 \%)$, maar de totale omvang van de bijzondere waardeverminderingen is met $4,4 \%$ lager dan die van de gehele populatie (7,3\%; zie tabel 2, kolom 'effect blijkens de jaarrekening'). Opvallend is dat geén enkele onderneming met een $\mathrm{PtB}<1$ een bijzondere waardever- 


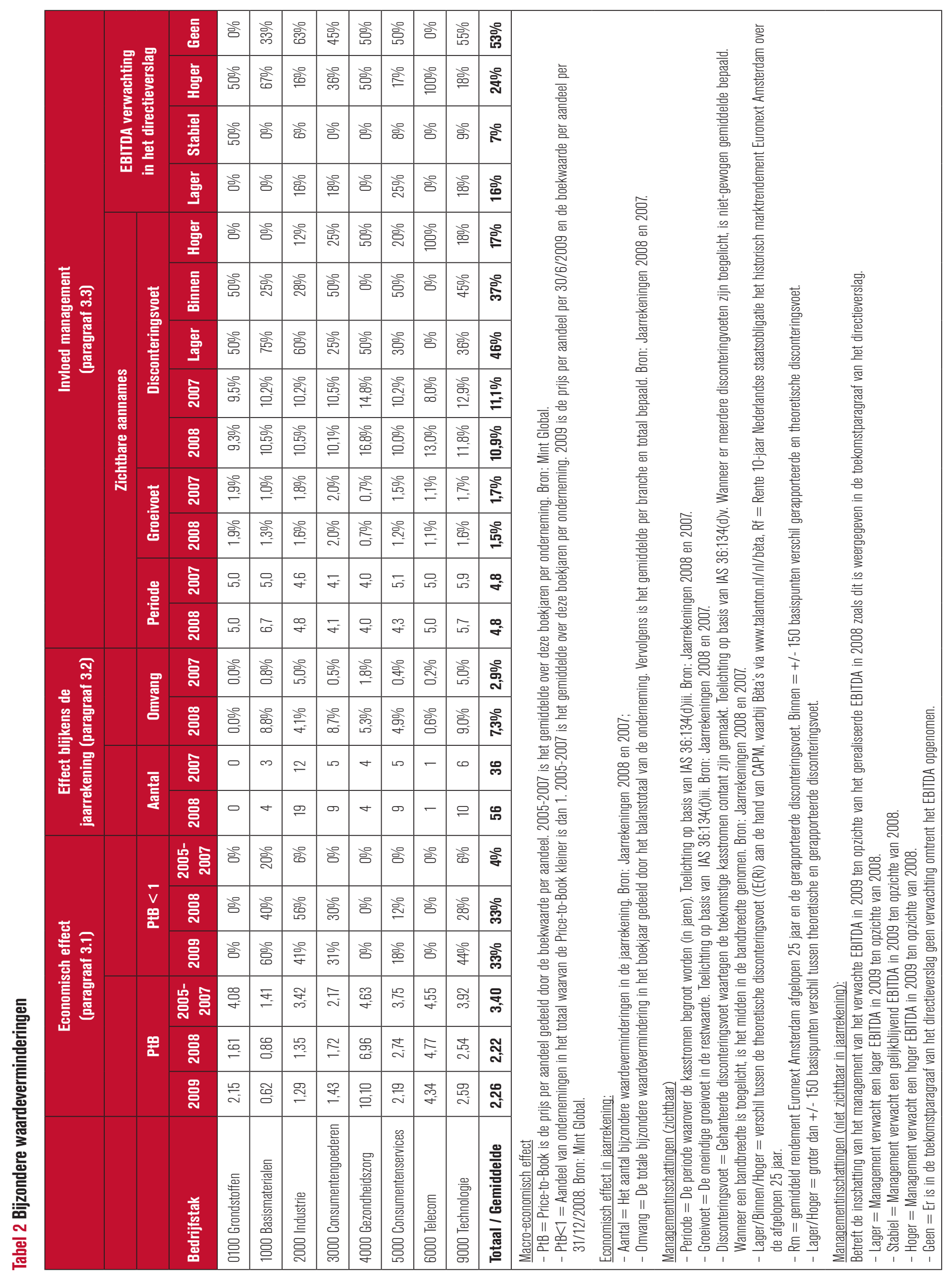


mindering heeft doorgevoerd die ertoe heeft geleid dat de $\mathrm{PtB} \geq 1$ is (zie tabel 2, subkolommen 'PtB 2009' en 'PtB<1 2009'). Dit is een indicatie dat het management klaarblijkelijk een andere inschatting heeft ten aanzien van de toekomst dan de kapitaalmarkt. Het is niet uit te sluiten dat hier sprake is van een (tijdelijke) marktimperfectie door overreactie van de kapitaalmarkt op informatie over de kredietcrisis.

In principe is bij een actief sprake van een bijzondere waardevermindering wanneer een onderneming niet in staat is de boekwaarde van een actief te realiseren door voortgezet gebruik of verkoop (de realiseerbare waarde). Het bedrijfseconomisch doel wordt door Knoops en Ter Hoeven (2007) beschreven: 'Eerder gemaakte rendementsverwachtingen blijken niet bewaarheid te worden waardoor de onderneming haar activa moet afwaarderen om op de resterende boekwaarde in ieder geval nog een normaal rendement te kunnen behalen.' Rendementsverwachtingen bij bijzondere waardeverminderingen betreffen in beginsel rendementsverwachtingen op (middel)lange termijn. Het is de vraag of de kredietcrisis naar verwachting een effect zal hebben op de (middel)lange termijn. Doordat ondernemingen met een $\mathrm{Pt} B<1$ hun boekwaarde niet hebben afgeboekt naar de lagere marktwaarde, lijkt de ondernemingsleiding met name van de kredietcrisis een kortetermijneffect te verwachten. Dit verschil in rendementsverwachting is zichtbaar in alle branches (tabel 2, kolom 'economisch effect'). Derhalve verwachten wij dat ondernemingsleidingen - dus ook van ondernemingen met een $P t B>1$ uitgaan van een kortetermijneffect en dat daarmee de invloed van de kredietcrisis op bijzondere waardeverminderingen beperkt is. Dit leidt tot de volgende hypothese:

Hza: De kredietcrisis heeft een beperkt effect op de rendementsverwachting op (middel)lange termijn en leidt derhalve tot een beperkte toename van de omvang van bijzondere waardeverminderingen.

IAS 36 inzake bijzondere waardevermindering van activa is een standaard die is uitgebracht in 1998. De directe aanleiding daarvoor was de (beoogde) toegenomen activering van immateriële vaste activa en het bestaan van een vergelijkbare standaard onder US GAAP (SFAS 121, zie Camfferman en Zeff, 2007, p. 381). Het doel van IAS 36 is '... voor te schrijven welke procedures een entiteit moet toepassen zodat haar activa niet tegen een hoger bedrag geboekt worden dan hun realiseerbare waarde' (IAS 36.1). De strikte wijze van formuleren van dit doel geeft aan dat de regelgever de (subjectieve) invloed van het management poogt te beteugelen. Dit aspect komt ook naar voren in een discussie in 1990 toen onder US GAAP op dit gebied regelgeving is ontwikkeld (zie tabel 3). Om tegemoet te komen aan de bezwaren van de tegenstanders, richt IAS 36 zich zo veel mogelijk op het objectiveren van het bepalen van bijzondere waardeverminderingen. Deze procedures in combinatie met controle door een accountant moeten zorgen voor vergelijkbaarheid tussen ondernemingen in tijdstip en omvang van bijzondere waardeverminderingen.

\section{Tabel 3 Argumenten voor- en tegenstanders bijzondere waardeverminderingen}

\begin{tabular}{|l|l|}
\hline \multicolumn{1}{|c|}{ Voorstanders } & \multicolumn{1}{c|}{ Tegenstanders } \\
\hline $\begin{array}{l}\text { Boekwaarde moet nooit hoger zijn } \\
\text { dan de realiseerbare waarde }\end{array}$ & $\begin{array}{l}\text { Subjectiviteit bij berekeningen } \\
\text { (prognosticeren van kasstromen en } \\
\text { disconteringsvoet) }\end{array}$ \\
\hline $\begin{array}{l}\text { Vlottende activa (voorraden en } \\
\text { debiteuren) worden ook gewaardeerd } \\
\text { tegen de laagste van de boekwaarde } \\
\text { en 'realiseerbare' waarde }\end{array}$ & $\begin{array}{l}\text { Toerekenen van kasstromen aan } \\
\text { individuele activa vaak moeilijk en } \\
\text { soms onmogelijk }\end{array}$ \\
\hline Bron: AICPA p. 12 & \\
\hline
\end{tabular}

Resumerend wordt de potentiële invloed van het management op de weergave van de economische realiteit bij bijzondere waardeverminderingen door regelgevers groot geacht. Daarbij komt dat door het wegvallen van de vraag en de economische krimp de vooruitzichten ten aanzien van de winstgevendheid voor ondernemingen aanzienlijk zijn verslechterd. Deze verslechtering kan zich (ten dele) vertalen in potentieel hogere bijzondere waardeverminderingen. De combinatie van deze ontwikkelingen leidt ertoe dat de invloed van het management op de weergave van de economische realiteit toeneemt. Op basis daarvan formuleren wij de volgende hypothese:

$\mathrm{H} 2 \mathrm{~b}$ : De invloed van het management op de weergave van de economische realiteit bij bijzondere waardeverminderingen neemt toe.

\subsection{Effect blijkens de jaarrekening}

Indien de realiseerbare waarde, dat is de hoogste van de indirecte opbrengstwaarde (bedrijfswaarde) en de reële waarde minus verkoopkosten, lager is dan de boekwaarde, dan is er sprake van een bijzondere waardevermindering en moet worden afgewaardeerd tot de lagere realiseerbare waarde. ${ }^{11}$

De bijzondere waardeverminderingen zijn in 2008 zowel in aantal (56) als in omvang (7,3\% van de boekwaarde van de totale vaste activa) aanzienlijk gestegen ten opzichte van 2007 (tabel 2, kolom 'economisch effect blijkens de jaarrekening'). ${ }^{12}$ Op brancheniveau ligt dit genuanceerder. Bij drie van de acht branches (basisgrondstoffen, industrie en telecom) is er in 2008 geen of nauwelijks sprake van een stijging van de omvang van de bijzondere waardevermindering. 
Het aantal ondernemingen dat afboekt op de goodwill die bij acquisities is betaald, is vergeleken met het voorgaande jaar verdubbeld (2008: 40\%, 2007: 20\%). De goodwillafboekingen die ondernemingen in hun jaarrekening 2008 verantwoorden, bedragen in totaal bijna 4 miljard euro, terwijl het in 2007 om een bedrag van in totaal 28 miljoen euro gaat. Gemiddeld hebben ondernemingen in 2008 $17,5 \%$ op de goodwill afgeschreven tegen gemiddeld 6,6\% in 2007. Naast afboekingen op goodwill zijn er ook afboekingen gedaan op andere immateriële vaste activa (waaronder geactiveerde ontwikkelingskosten, software, merken en uitgavenrechten) en materiële vaste activa. De afboekingen op andere immateriële vaste activa zijn in 2008 verdrievoudigd en bedragen in totaal 288 miljoen euro (2007: 88 miljoen euro). De afboekingen op materiële vaste activa (waaronder bedrijfsgebouwen en machines) zijn in 2008 met $16 \%$ gestegen ten opzichte van 2007.

Hypothese 2a kunnen wij gedeeltelijk bevestigen. Op het totaal van de ondernemingen is er sprake van een stijging, zij het dat deze veroorzaakt wordt door enkele grote afboekingen. Voor enkele bedrijfstakken is er in 2008 geen sprake van een stijging van de omvang van bijzondere waardeverminderingen

3.3 Invloed management op de weergave economische realiteit Wat is de invloed van het management op de weergave van de economische realiteit? Om deze vraag te kunnen beantwoorden, is het van belang om te bezien hoe een bijzondere waardevermindering wordt bepaald. De realiseerbare waarde wordt, indien er sprake is van kasstroomgenererende eenheden onder IFRS, bepaald op basis van een contantewaardeberekening, waarbij een onderscheid wordt gemaakt in een prognoseperiode en een restwaarde. ${ }^{13}$ De berekening ziet er als volgt uit:

$R V=\sum \frac{N C F}{(1+i)^{n}}+\frac{R C F * G V}{i}$

en bevat de volgende schattingselementen:

- de verwachte kasstroom gedurende de prognoseperiode (NCF) en de lengte van de prognoseperiode $(n)$;

- de verwachte resterende kasstroom na afloop van de prognoseperiode (RCF) en de gehanteerde groeivoet (GV);

- de gehanteerde disconteringsvoet $(1+i, i)$.

\section{Zichtbare aannames}

IFRS vereist een jaarlijkse toelichting van de lengte van de prognoseperiode (IAS 36.134d (iii)), de groeivoet (IAS 36.134d (iv)) en de disconteringsvoet (IAS 36.134d (v)), waardoor wijzigingen hierin observeerbaar zouden moeten zijn. Het ligt voor de hand om eerst te beoordelen of hier veranderingen zijn waar te nemen. Zoals blijkt uit tabel 2 (kolom 'zichtbare aannames' subkolommen '2008' en '2007') zijn de gemiddelden van de in de jaarrekening observeerbare aannames (lengte prognoseperiode, gehanteerde groeivoet en de disconteringsvoet) in 2008 ten opzichte van 2007 nauwelijks gewijzigd. De standaarddeviatie is daarbij ook niet veranderd. Daarbovenop hebben wij per onderneming vastgesteld dat er nauwelijks significante wijzigingen zijn in genoemde observeerbare aannames.

Verwachten we een verschil in deze aannames als gevolg van de kredietcrisis? Ten eerste is niet te verwachten dat de prognoseperiode verandert in 2008 als gevolg van de kredietcrisis. Mogelijk dat de crisis ertoe zou leiden dat er meer onzekerheid is bij het schatten van de kasstromen over de prognoseperiode, wat de lengte van de prognoseperiode zou kunnen verkorten. Kennelijk is deze onzekerheid onvoldoende groot om tot een kortere schattingsperiode over te gaan. Een langere schattingsperiode is overigens ook niet te verwachten daar IAS 36.35 aangeeft dat doorgaans betrouwbare financiële voorspellingen over perioden van meer dan vijf jaar niet beschikbaar zijn.

De groeivoet wordt bepaald door economische groei op lange termijn. De relatie tussen conjunctuur en de groeivoet is echter niet evident: een laagconjunctuur hoeft nog niet te betekenen dat op lange termijn de groeiverwachtingen van een onderneming anders zijn. Derhalve is het niet opvallend dat de gehanteerde gemiddelde groeivoet alsmede verschillen hierin per bedrijfstak in lijn liggen met macro-economische cijfers. ${ }^{14}$

In principe verandert in een crisis of laagconjunctuur het totale marktrisico niet, dat wil zeggen dat de risico-opslag voor aandelen vertaald in de rendementseis van beleggers en de disconteringsvoet op basis hiervan niet veranderen. De rente op de kapitaalmarkt (tienjarige staatslening) is in 2008 (ten opzichte van 2007) licht gestegen (in 2009 is de rente weer wat gedaald). Naar verwachting hebben renteschommelingen dan ook geen groot effect op de disconteringsvoet. Bij de disconteringsvoet is er een mogelijkheid om de invloed van het management op de weergave van de economische realiteit nader te kwantificeren. IFRS stelt expliciet een link tussen de te hanteren disconteringsvoet voor de berekening van de bijzondere waardevermindering en het Capital Asset Pricing Model (CAPM; Fama, 1968) doordat bij de bepaling van de disconteringsvoet rekening wordt gehouden met 'de rendementseis die beleggers zouden stellen...' (IAS 36.56) en 'als de markt geen specifieke disconteringsvoet voor het actief kent...' (IAS 36.57). Het is mogelijk om aan de hand van CAPM een theoretische disconteringsvoet te berekenen voor de betreffende onderneming. ${ }^{15}$ We hebben deze theoretische disconteringsvoet vergeleken met de (niet-gewogen) gemiddelde toegelichte 
disconteringsvoet in de jaarrekening 2008 zoals deze op basis van IAS 36 toegelicht moet worden. Analoog aan Carlin en Finch (2009) stellen wij dat een afwijking van 150 basispunten naar boven of beneden binnen de schattingsbandbreedte valt van het CAPM en/of de werkelijk gehanteerde disconteringsvoet, zijnde mogelijke meetfouten. ${ }^{16}$ Dit betreft $37 \%$ van de ondernemingen (tabel 2, kolom: 'disconteringsvoet' subkolom 'binnen'). Opvallend is dat voor het gedeelte van de observaties buiten de schattingsbandbreedte $46 \%$ lager en maar $17 \%$ hoger is (tabel 2 kolom: 'disconteringsvoet' subkolom 'hoger' en 'lager'). Deze resultaten zijn vergelijkbaar met het onderzoek van Carlin en Finch (2009) die op dezelfde wijze de afwijking tussen de theoretische disconteringsvoet en de toegelichte disconteringsvoet hebben bepaald. Op basis van de resultaten concluderen zij dat er mogelijk sprake kan zijn van opportunisme van het management. Wij sluiten niet uit dat de resultaten (gedeeltelijk) gedreven kunnen zijn door de methode voor het bepalen van de theoretische disconteringsvoet alsmede de wijze van bepalen van de gerapporteerde disconteringsvoet per onderneming. Een mogelijke consequentie van deze resultaten is dat de gerapporteerde bijzondere waardeverminderingen in realiteit hoger zouden moeten zijn.

Wij hebben dezelfde verschillen (tussen toegelichte en theoretische disconteringsvoet) bepaald voor de jaarrekening 2007. De resultaten zijn vergelijkbaar met 2008, wat suggereert dat het opportunisme van het management bij weergave van de economische realiteit voor wat betreft de disconteringsvoet door de kredietcrisis niet is veranderd. Derhalve kunnen we ten aanzien van de disconteringsvoet hypothese $2 \mathrm{~b}$ niet bevestigen.

\section{Niet-zichtbare aannames}

Voorgaande betekent dat het niet onaannemelijk is dat de niet-observeerbare aannames (de verwachte kasstroom gedurende prognoseperiode en de restkasstroom) de verdriedubbeling van de omvang van de bijzondere waardevermindering in 2008 hebben veroorzaakt. De verdeling van de aanpassing in de nettokasstroom over de kasstromen gedurende de prognoseperiode (middellange termijn) en de restkasstroom (lange termijn) is niet direct op basis van de in de jaarrekening beschikbare gegevens vast te stellen doch wel indirect te beredeneren. Aangezien er geen verandering is in de gehanteerde groeivoet na de prognoseperiode, is het ook niet voor de hand liggend dat in 2008 door het management een grote verandering in de restkasstroom na afloop van de prognoseperiode heeft plaatsgevonden. Wij concluderen dat het niet onredelijk is om te veronderstellen dat waarschijnlijk de grootste veroorzaker van de toegenomen frequentie en omvang van de bijzondere waardeverminderingen de wijziging van de kasstromen in de prognoseperiode is. IFRS stelt specifieke regels hoe de kasstromen voor de prognoseperiode te schatten. De belangrijkste zijn:

- verwachte kasstromen ten aanzien van de huidige toestand van het actief, dat wil zeggen geen rekening houden met prestatieverbeteringen of kostenbesparingen (IAS 36.44);

- kasstromen uit financieringsactiviteiten worden niet meegenomen, omdat die zijn 'opgesloten' in de discontering van de kasstromen (tijdswaarde van geld, IAS 36.51);

- belastingeffecten worden niet meegenomen, aangezien deze ook niet meegenomen worden in de disconteringsvoet (IAS 36.51);

- wanneer bij reorganisaties wordt voldaan aan de criteria voor het vormen van een reorganisatievoorziening (IAS 37.72) dan wordt het netto-effect (het verschil tussen de uitgaven in verband met de reorganisatie en de besparingen/voordelen) meegenomen bij de bepaling van de kasstromen (IAS 36.47).

Deze specifieke regels beperken de vrijheid van het management ten aanzien van het bepalen van de kasstromen en moeten een betere vergelijkbaarheid (in de tijd en tussen ondernemingen) bij bijzondere waardeverminderingen bewerkstelligen. Bovendien stelt IAS 36.34 dat het management ervoor moet zorgen dat de veronderstellingen waarop de kasstroomprognoses zijn gebaseerd, consistent zijn met feitelijke resultaten uit het verleden. Het ligt voor de hand om eerst te bezien of de gerealiseerde resultaten in 2008 (in vergelijking met de referentieperiode) indicaties geven voor de toename van de bijzondere waardeverminderingen. Gerealiseerde resultaten (kasstroom/omzet, brutomarge, EBITDA) en inschattingen van het management van het toekomstig resultaat op korte termijn (voorziening voorraden, voorziening debiteuren) kunnen indicatoren zijn voor de middellange winstgevendheid van een onderneming. ${ }^{17}$ Zoals uit bijlage 3 blijkt, verslechteren genoemde indicatoren in 2008 (ten opzichte van de referentieperiode) slechts marginaal en lijken daarmee niet de verdriedubbeling van de bijzondere waardeverminderingen in 2008 te verklaren.

Een alternatieve manier om te zien hoe het management de toekomstige winstgevendheid van de onderneming inschat, is de toekomstige winstgevendheid in de toekomstparagraaf van het directieverslag te analyseren. De resultaten zijn opgenomen in tabel 2, kolom 'EBITDA verwachting in het directieverslag'. In het totaal geeft het management van $53 \%$ van de ondernemingen geen inschatting van de verwachte EBITDA voor 2009 en/of de jaren daarna. Van deze 53\% geeft $64 \%$ (34\% van het totaal) expliciet als oorzaak aan dat door de toegenomen onzeker- 
heid als gevolg van de kredietcrisis het niet mogelijk is om in kwantitatieve dan wel kwalitatieve zin een uitspraak te doen over de EBITDA. Dit lijkt inconsistent te zijn met de verdriedubbeling van de bijzondere waardeverminderingen, die mede gebaseerd is op een inschatting van de middellange toekomstige winstgevendheid en, zoals eerder betoogd, waarschijnlijk de belangrijkste determinant is van de stijging van de bijzondere waardeverminderingen. Het is tevens opvallend dat van de $47 \%$ van de ondernemingen die wél een uitspraak doen over de EBITDA over 2009, 51\% (24\% van het totaal) een verbetering verwacht ten opzichte van 2008 tegenover $34 \%$ ( $16 \%$ van het totaal) een verslechtering. De overige ondernemingen (15\%) verwachten dat EBITDA stabiel blijft. Dit lijkt ook inconsistent te zijn met de verdriedubbeling van de bijzondere waardeverminderingen in 2008. De optimistische verwachtingen ten aanzien van EBITDA lijken niet in lijn te liggen met de toename van de omvang van de bijzondere waardeverminderingen. Mogelijk dat deze schijnbare inconsistentie verklaard kan worden doordat de kasstroomprognoses die ten grondslag liggen aan de berekening van de realiseerbare waarde van activa niet zichtbaar opgenomen zijn in de jaarverslaggeving en de verwachtingen ten aanzien van de EBITDA wel. Het lijkt erop dat het management wel impliciet slecht nieuws wil berichten aangaande de verwachte EBITDA door een toename van de bijzondere waardevermindering doch niet expliciet bij het beschrijven van de verwachte EBITDA voor 2009 en verder. ${ }^{18}$ Derhalve kunnen wij hypothese $2 \mathrm{~b}$ aangaande de invloed van het management op de nietzichtbare aannames gedeeltelijk bevestigen.

\section{Vorming van reorganisatievoorzieningen}

\subsection{Hypothesevorming}

Het Centraal Planbureau ( $\mathrm{CPB}$ ) verwacht als gevolg van de kredietcrisis een verdubbeling van de werkeloosheid in Nederland naar 600.000 mensen. ${ }^{19}$ Voorspellingen door planbureaus in andere landen zijn vergelijkbaar. Een dergelijke toename van de werkeloosheid in een relatief kort tijdsbestek kan veelal niet bereikt worden door regulier verloop van personeel, maar gaat gepaard met reorganisaties en zou derhalve moeten leiden tot meer en hogere reorganisatievoorzieningen.

Onder IFRS (IAS 37.14) wordt een voorziening gevormd wanneer aan drie criteria wordt voldaan: er is sprake van een - in rechte afdwingbare of feitelijke - verplichting, het is waarschijnlijk dat er een uitstroom van middelen is en de omvang kan betrouwbaar worden bepaald. In verband met het mogelijk gebruik van reorganisatievoorzieningen als instrument van winststuring (met name big bath accounting) zijn onder IFRS (IAS 37.72) de volgende aanvullende voorwaarden gesteld voor het treffen van een reor- ganisatievoorziening op balansdatum (zie Mulford \& Comiskey (2002)) :

- er moet een formeel plan zijn waarin de details van de reorganisatie, de verwachte uitgaven en het tijdstip van uitvoering worden beschreven;

- bij de betrokkenen is een geldige verwachting gewekt dat het reorganisatieplan uitgevoerd zal worden. Hiertoe zal minimaal het plan vóór of op balansdatum aan betrokkenen kenbaar zijn gemaakt (IAS 37.75).

Met deze eisen heeft de IASB een afweging gemaakt tussen betrouwbaarheid en relevantie ten faveure van eerstgenoemde. Omdat de kredietcrisis zich manifesteerde in het derde kwartaal van 2008, verwachten wij dat veel ondernemingen op balansdatum (31 december 2008) nog niet aan de aanvullende eisen hebben voldaan. Dit leidt tot de volgende hypothese:

$\mathrm{H}_{3}$ : Gegeven de aanvullende bepalingen onder IFRS voor het vormen van reorganisatievoorzieningen, leidt de kredietcrisis tot een beperkte toename van de reorganisatievoorzieningen in de jaarrekening 2008.

\subsection{Effect blijkens de jaarrekening}

In tabel 4 kan worden afgelezen dat het aantal ondernemingen met reorganisatievoorzieningen nauwelijks is toegenomen (van 44 in 2007 naar 46 in 2008). Daarbij hadden 42 van de 46 ondernemingen met een reorganisatievoorziening in 2008 deze ook al in 2007, dat wil zeggen dat er in 2008 maar vier ondernemingen met een reorganisatievoorziening zijn bijgekomen.

In het onderzoek komt naar voren dat het kortlopende gedeelte van de reorganisatievoorziening gemiddeld met $14 \%$ is gestegen naar 25,3 miljoen euro, wat een indicatie is dat het management van ondernemingen besloten heeft gemiddeld meer te reorganiseren (zie tabel 4 kolom 'omvang kortlopend'). Doordat de standaarddeviatie is afgenomen, lijken ondernemingen ook eensgezinder over de omvang van de reorganisaties op korte termijn. Het is opvallend dat de stijging van het langlopend gedeelte van de reorganisatievoorziening (70\%) in 2008 aanzienlijk hoger is dan de stijging in het kortlopend gedeelte van de reorganisatievoorziening (14\%). Dit is mogelijk een indicatie dat het management niet de noodzaak ziet om op korte termijn ingrijpend te saneren, maar nog voldoende mogelijkheden ziet om dit op middellange termijn te doen. Deze bevindingen ondersteunen hypothese 3 , omdat de toename van de reorganisatievoorzieningen niet in verhouding lijkt te staan tot het door het $\mathrm{CPB}$ voorspelde verdubbeling van het aantal werkelozen. Daar komt nog bij dat veel beursfondsen internationaal opereren en de kredietcrisis in vele landen leidt tot een naar verwachting sterkere toename van de werkeloosheid. 
Tabel 4 Reorganisaties op korte en lange termijn

\begin{tabular}{|c|c|c|c|c|c|c|c|c|c|c|}
\hline \multirow{3}{*}{ Bedriffstak } & \multicolumn{6}{|c|}{ Effect blfjkens de jaarrekening (paragraaf 4.2) } & \multicolumn{4}{|c|}{$\begin{array}{l}\text { Invloed management//FRS-regelgeving } \\
\text { (paragraaf 4.3) }\end{array}$} \\
\hline & \multicolumn{2}{|c|}{ Aantal } & \multicolumn{2}{|c|}{ Omvang kortlopend } & \multicolumn{2}{|c|}{ Omvang langlopend } & \multicolumn{2}{|c|}{ Directieverslag } & \multirow{2}{*}{$\begin{array}{l}\text { Halfjaar- } \\
\text { verslag } \\
2009\end{array}$} & \multirow{2}{*}{$\begin{array}{l}\text { Trading } \\
\text { update } \\
\text { Q3-2009 }\end{array}$} \\
\hline & 2008 & 2007 & 2008 & 2007 & 2008 & 2007 & 2007 & 2008 & & \\
\hline 0100 Grondstoffen & 1 & 1 & 0,1 & 0,1 & 0,2 & 0,1 & $0 \%$ & $0 \%$ & $0 \%$ & $0 \%$ \\
\hline 1000 Basismaterialen & 3 & 3 & 37,4 & 58,4 & 24,5 & 20,1 & $50 \%$ & $50 \%$ & $50 \%$ & $50 \%$ \\
\hline 2000 Industrie & 17 & 18 & 11,5 & 7,3 & 10,8 & 8,4 & $21 \%$ & $29 \%$ & $79 \%$ & $79 \%$ \\
\hline 3000 Consumentengoederen & 7 & 7 & 81,0 & 80,0 & 50,4 & 22,9 & $0 \%$ & $10 \%$ & $20 \%$ & $30 \%$ \\
\hline 4000 Gezondheidszorg & 2 & 1 & 0,4 & 0,3 & 0,1 & 0,1 & $0 \%$ & $0 \%$ & $33 \%$ & $33 \%$ \\
\hline 5000 Consumentenservices & 10 & 9 & 17,8 & 12,0 & 10,4 & 7,5 & $0 \%$ & $0 \%$ & $57 \%$ & $57 \%$ \\
\hline 6000 Telecom & 1 & 1 & 107,0 & 44,0 & 131,0 & 39,0 & - & - & - & - \\
\hline 9000 Technologie & 5 & 4 & 3,5 & 0,8 & 4,1 & 1,2 & $15 \%$ & $42 \%$ & $75 \%$ & $75 \%$ \\
\hline Totaal / Gemiddelde & 46 & 44 & 25,3 & 22,1 & 19,5 & 11,5 & $12 \%$ & $24 \%$ & $57 \%$ & $59 \%$ \\
\hline Standaarddeviatie & & & 69,6 & 84,1 & 35,9 & 19,3 & & & & \\
\hline \multicolumn{11}{|c|}{$\begin{array}{l}\text { Effecten blijkens de jaarrekening (par. 4.2) } \\
\text { - Aantal = het aantal ondernemingen met een reorganisatievoorziening in boekjaar (bron: jaarrekeningen } 2008 \text { en 2007). } \\
\text { - Omvang kortlopend = het gedeelte van de reorganisatievoorziening met een looptijd korter dan een jaar. Bedragen in miljoenen. } \\
\text { - Omvang langlopend = het gedeelte van de reorganisatievoorziening met een looptijd langer dan een jaar. Bedragen in miljoenen. }\end{array}$} \\
\hline
\end{tabular}

4.3 Invloed management op weergave economische realiteit In onderzoek van Overboom en Vergoossen (1997) ten aanzien van voorzieningen in het algemeen en van Ter Hoeven (1997) ten aanzien van reorganisatievoorzieningen in het bijzonder, wordt de invloed van het management op de weergave van de economische realiteit onder Nederlandse beursgenoteerde ondernemingen beschreven. Beide onderzoeken laten zien dat de omvang van voorzieningen wordt beïnvloed door het management. Daarnaast stelt Ter Hoeven (2005) terecht dat onder IFRS, ondanks aanvullende voorwaarden ter onderbouwing van het bestaan van een verplichting bij reorganisatievoorzieningen, afhankelijk van het communicatietraject in de richting van de betrokkenen het moment van opnemen van de voorziening kan worden gestuurd. In de praktijk zal deze sturing veelal zodanig worden vormgegeven dat het leidt tot een vertraging in de opname van een reorganisatievoorziening.

Dit komt ook in ons onderzoek naar voren. Het blijkt namelijk dat van de 53 ondernemingen die in 2008 geen reorganisatievoorziening hebben opgenomen, $24 \%$ in het directieverslag bij de jaarrekening 2008 termen als 'reorganisatie', 'kostenreductie' en 'afvloeiingsregelingen' (tabel 4 , kolom 'directieverslag') noemt ten opzichte van $12 \%$ in 2007. Er is dus sprake van een verdubbeling van (voorgenomen) reorganisaties bij ondernemingen die zich niet een op een vertalen in het opnemen van reorganisatievoorzieningen.

Om te beoordelen hoe zich dat in de loop van 2009 verder heeft ontwikkeld, hebben wij ook de halfjaarverslaggeving en de trading update over het derde kwartaal van 2009 van de betrokken ondernemingen onderzocht (tabel 4, kolom 'haljaarverslag' en 'trading update'). In de halfjaarverslaggeving 2009 komt naar voren dat het percentage ondernemingen dat in haar halfjaarverslag melding maakt van (voorgenomen) reorganisaties is gestegen naar 57. In de trading update over het derde kwartaal maakt zelfs $59 \%$ van de ondernemingen die in 2008 geen reorganisatievoorziening hebben opgenomen melding van (voorgenomen) reorganisaties. 
Het is niet direct te duiden of de stijging veroorzaakt wordt doordat reorganisaties die in 2008 reeds voorgenomen waren, nu pas genoemd worden of dat de beslissing om te reorganiseren pas in de loop van 2009 is genomen. Niettemin lijkt er sprake te zijn van een vertraging in het verantwoorden van reorganisatievoorzieningen. Ook deze bevindingen ondersteunen hypothese 3 .

\section{Conclusies}

Het in dit artikel gepresenteerde empirisch onderzoek leidt tot de volgende conclusies:

- Ondernemingen lijken te worden beperkt in hun mogelijkheden om bestaand krediet te behouden of om nieuw krediet te verkrijgen. Uit de jaarrekeningen 2008 blijkt dat zeven keer zoveel ondernemingen niet meer aan de kredietvoorwaarden voldoen en - wanneer bestaande convenanten de basis zijn voor het verstrekken van nieuwe kredieten - het moeilijker wordt nieuwe activiteiten te financieren. Deze effecten zijn het sterkst in de branches industrie en technologie. Bovendien lijkt er sprake te zijn van een toename van de invloed van het management op de weergave van de economische realiteit.

- In de jaarrekeningen 2008 is zowel het aantal bijzondere waardeverminderingen als hun omvang sterk gestegen, zij het dat dit zich concentreert in enkele bedrijfstakken. De voor de hand liggende verklaring op basis van de analyse is een verlaagde inschatting van de winstgevendheid gedurende de eerste vijf jaar. De gehanteerde disconteringsvoeten lijken aan de lage kant, wat kan duiden op opportunisme bij het management. Dit opportunisme lijkt echter niet toegenomen door de kredietcrisis. Tevens zijn er inconsistenties te bespeuren tussen de verlaagde inschatting van de winstgevendheid in de toets op bijzondere waardeverminderingen en de verwachtingen die in het directieverslag naar voren komen ten aanzien van het verwachte resultaat over 2009. Of deze inconsistenties veroorzaakt worden door een toegenomen invloed van het management op de weergave van de economische realiteit, is op basis van het jaarrekeningonderzoek niet vast te stellen.

- De in het boekjaar 2008 door de ondernemingen in hun jaarrekening verantwoorde reorganisatiekosten zijn meer dan verdubbeld en gestegen naar ruim 2,2 miljard euro. Ondernemingen geven aan dat $60 \%$ van de ultimo 2008 gevormde reorganisatievoorzieningen binnen één jaar zal worden aangesproken. De stijging van de reorganisatievoorzieningen lijkt niet in verhouding te staan tot de omvang van de economische crisis. Dit kan mogelijk worden verklaard doordat er sprake is van een vertragend effect bij het vormen van reorganisatievoorzieningen door de aanvullende voorwaarden die IFRS hieraan stelt. Mogelijk dat een toegenomen invloed van het management op de weergave van de economische realiteit een rol speelt. Zo maakt $24 \%$ van de ondernemingen zonder reorganisatievoorziening wel melding van een reorganisatie in het directieverslag ten opzichte van $12 \%$ in 2007.

Drs. H.J.R. Litjens RA is senior manager bij Bureau

Vaktechniek van BDO en onderzoeker bij Nyenrode Business

Universiteit.

Prof. dr. R.G.A. Vergoossen RA is partner bij Bureau

Vaktechniek van BDO en hoogleraar Nyenrode Business

Universiteit en Maastricht University.

\section{Literatuur}

- AICPA Task Force on impairment of value (1980), Accounting for the inability to fully recover the carrying amounts of long lived assets, American Institute of Certified Public Accountants (AICPA).

- Bliss, J.H. (1924), Management through accounts, New York: The Ronald Press Co. - Basu S. (1997), The conservatism principle and the asymmetric timeliness of earnings, Journal of Accounting and Economics, vol. 24, pp. 3-37.

Burgstahler, D en I. Dichev (1997), Earnings management to avoid earnings decreases and losses, Journal of Accounting and Economics, vol. 24, pp. 99-126.

ש Durtschi, C. en P. Easton (2005), Earnings Management? The shapes and frequency
Distributions of Earnings management are not evidence Ipso Facto, Journal of Accounting Research, vol. 43, no. 4, pp. 557-592. - Durtschi, C. en P. Easton (2009), Earnings Management? Erroneous inferences based on earnings frequency distributions, Journal of Accounting Research, vol. 47, no. 5, pp. 1249-1281.

- Camfferman, K. en S.A. Zeff (2007), Financial reporting and global capital markets, A history of the International Accounting Standards Committee, 1973-2000, Oxford University Press.

- Carlin, T. en N. Finch (2009), Discount rates in disarray: Evidence on flawed goodwill impairment testing, working paper (available at SSRN: http://ssrn.com/abstract=1283647).
Eshuis K. en M. Wolzak (2009), 'Uitgifte converteerbare obligaties neemt een nieuwe vlucht door de kredietcrisis' Het Financieele Dagblad, vrijdag 19 juni, Ondernemen en Beleggen, p. 9 .

- Fama, E.F. (1968), Risk, return and equilibrium: Some clarifying comments, Journal of Finance, vol. 23, no. 1, pp. 29-40, - Hamada, R.S. (1972), The effect of the firms' capital structure on the systematic risk of common stock, Journal of Finance, vol. 27, pp. 435-452.

- Hoeven, R.L. ter (2005), Principle-based versus rule-based accounting standards, Maandblad voor Accountancy en Bedrijfseconomie, vol. 79, no. 10, pp. 475-485.

- Hoeven, R.L. ter (1997), Reorganisatie en 
jaarrekening, proefschrift Erasmus Universiteit Rotterdam, Den Haag: Delwel.

- Jacob, J. en B. Jorgenson (2007), Earnings management and accounting income aggregation, Journal of Accounting and Economics, vol. 43, pp. 369-390.

- Klaauw, M. van der (2008), Kredietcrisis treft bedrijven, Het Financieele Dagblad, Optiek, 27 januari, pp. 7.

- Knoops C.D. en R.L. Ter Hoeven (2007),

Biizondere waardeverminderingen en

terugnemingen daarvan, in: Het jaar 2006

verslagen, Onderzoek jaarverslagen

ondernemingen (onder redactie van R. Bosman,
C. Camfferman en R.G.A. Vergoossen), Koninklijk NIVRA/Kluwer, Amsterdam/Deventer, 2007, pp. 87-125.

Mulford C.W en E.E. Comiskey (2002), The financial numbers game, Detecting creative accounting practices, Wiley and Sons Inc.

- Onbekend (2008), Minder leningen sinds uitbreken kredietcrisis, Het Financieele Dagblad, 18 februari, p. TEO28.

- Onbekend (2008), Kredietcrisis bijt pas echt in 2009, Het Financieele Dagblad, 16 februari, p. 19.

— Overboom, C.P.M. en R.G.A. Vergoossen

(1997), Voorzieningen en jaarrekeningbeleid,
Maandblad voor Accountancy en Bedrijfseconomie, jg. 71, no. 6, pp. 405-416.

- Riedl, E.J. en S. Srinivasan (2009), Signalling

firm performance through financial statement presentation: An analysis using special items, Contemporary Accounting Research, Forthcoming (available at SSRN: http://ssrn. com/abstract=923898)

- Vergoossen R.G.A. en Litjens H.J.R. (2009), Lagere waarde op beurs leidt niet tot afwaardering, Het Financieele Dagblad, 23 juli, Optiek, pp. 6.

Noten

1 Bron: http://www.boncherry.com/ blog/2008/10/22/the-credit-crunch-a-fewquotable-quotes/.

2 Zie bijvoorbeeld: http://www.accountant.nl/Accountant/Nieuws/EU-ministers+neem+fair+value-aanpassingen+VS+over.

3 Een lijst met onderzochte ondernemingen is opgenomen in bijlage 1.

4 Zie descriptieve statistiek (per branche) betreffende de grootte van de onderzochte ondernemingen in bijlage 2 .

5 De geschaalde variabelen in dit onderzoek zijn: i) de omvang van de bijzondere waardevermindering (tabel 2, uitgedrukt als percentage van de totale boekwaarde vaste activa):

ii) het overzicht van gerealiseerde resultaten (bijlage 3). Kasstroom, brutomarge en EBITDA zijn geschaald door omzet. Voorziening voorraden en voorziening debiteuren zijn geschaald door de waarde van respectievelijk de voorraden en debiteuren.

6 Onderzoek PricewaterhouseCoopers: 'The day after tomorrow'. Te downloaden via: http://www. pwc.com/extweb/onlineforms.nsf/docid_response/521E82E29B018CD58025755500368F2E ?OpenDocument\&.

$\mathbf{7}$ Ondernemingen moeten op grond van IFRS 7.7 ook informatie verschaffen over het aanwezig zijn van convenanten in kredietovereenkomsten (ook als er géén sprake is van het niet-nakomen daarvan) wanneer deze convenanten van belang zijn voor de beoordeling van financiële positie en prestaties van een onderneming.
8 Indien de bestaande convenanten niet de basis zijn voor het verstrekken van nieuwe kredieten. dan zullen deze, als gevolg van de kredietcrisis, hoger zijn. De risico's voor financiers zijn door de crisis omhoog gegaan en zij zullen door middel van hogere convenanten meer veiligheid inbouwen. Dit betekent dat onze resultaten door het hanteren van convenanten in bestaande kredietovereenkomsten mogelijk te laag zijn weergegeven.

9 Conservatisme is een bekend fenomeen in de verslaggeving dat uitdrukking geeft aan de asymmetrische pay-off tussen eigenvermogenverschaffers en vreemdvermogenverschaffers. Door conservatief te rapporteren, wordt tegemoetgekomen aan de vreemdvermogenverschaffers die tijdige signalen willen hebben dat het minder goed gaat met de onderneming. Bliss (1924) noemt dit 'anticipate all losses and no profits'. Zie bijvoorbeeld ook Basu (1997), die conservatisme definieert als: 'the accountants tendency to require a higher degree of verification to recognize good news as gains to recognize bad news as losses'. Conservatisme kan gezien worden als een soort bescherming voor vreemdvermogenverschaffers. Het leidt ertoe dat kredietverschaffers eerder een signaal krijgen dat een onderneming mogelijk niet aan rente- en aflossingsverplichtingen kan voldoen. Aan de hand van de convenanten in kredietovereenkomsten kunnen kredietverstrekkers dan tijdig ingrijpen.

10 IAS 36.9 stelt dat een onderneming aan het eind van elke verslagperiode moet beoordelen of er een indicatie is die wijst op een mogelijke bijzondere waardevermindering. Dit geldt niet voor kasstroomgenererende eenheden met toegerekende goodwill en/of immateriële vaste activa met een oneindige levensduur. Hiervoor geldt op basis van IAS 36.11 dat jaarlijks onderzocht moet worden of er sprake is van een bijzondere waardevermindering. Het tijdstip van deze toets is vrij, mits deze elk jaar op hetzelfde tijdstip wordt uitgevoerd (IAS 36.96). Voor ondernemingen met een $\mathrm{PtB}<1$ is hier een spanningsveld. Als de jaarlijkse test of zich een bijzondere waardevermindering heeft voorgedaan in januari wordt uitgevoerd én op balansdatum de $\mathrm{P}+\mathrm{B}<1$ is, moet dan nogmaals een test of zich een bijzondere waardevermindering heeft voorgedaan, worden uitgevoerd? IFRS stelt hierover niets expliciet. Praktijkervaring leert ons dat de overgrote meerderheid van de ondernemingen de jaarlijks verplichte test of zich een bijzondere waardevermindering heeft voorgedaan aan het eind van het boekjaar uitvoert, waardoor het in de praktijk mee zal vallen. Voor het onderzoek nemen we aan dat de test op balansdatum is uitgevoerd. 11 Voor activa anders dan goodwill in een kasstroomgenererende eenheid kan vaak ook de reële waarde minus verkoopkosten bepaald worden. Wanneer uit de toets of zich een bijzondere waardevermindering heeft voorgedaan, blijkt dat de bedrijfswaarde lager is dan de boekwaarde, wordt eerst de goodwill afgeboekt (IAS 36.104a). Wanneer er dan nog een af te boeken bedrag overblijft, wordt dit bedrag afgeboekt van de overige activa tot maximaal de reële waarde minus verkoopkosten van dat actief (IAS 36.104b en IAS 36.105). In situaties dat de directe opbrengstwaarde van de individuele activa in stand 
is gebleven, kan het voorkomen dat een bijzonder waardeverminderingverlies niet volledig wordt verwerkt. Indien hier sprake van is, moet een verplichting opgenomen worden als dit door een andere standaard is voorgeschreven (IAS 36.108). Wij hebben dergelijke situaties niet aangetroffen in de door ons onderzochte jaarrekeningen.

12 De frequentie bijzondere waardeverminderingen van 36\% voor het boekjaar 2007 ligt in lijn met het onderzoek van Knoops en Ter Hoeven (pagina 98) voor de jaren 2005 en 2006. De onderzoekspopulatie van Knoops en Ter Hoeven betreft honderd Europese ondernemingen. Derhalve lijkt 2007 ten aanzien van de frequentie bijzondere waardeverminderingen een normaal jaar te zijn. De omvang van bijzondere waardeverminderingen van gemiddeld 2,9\% van het totaal van de vaste activa komt niet voor in het onderzoek van Knoops en Ter Hoeven. Zij relateren de omvang van de bijzondere waardevermindering aan het operationeel resultaat en concluderen dat in 13 van de 60 (21\%) ondernemingen de bijzondere waardevermindering groter is dan $4 \%$ van het operationeel resultaat. Voor 2007 is dit voor onze onderzoekspopulatie 16 van de 93 (17\%). Voor boekjaar 2008 is dit 42\%.

13 Alle bijzondere waardeverminderingen bij de onderzochte ondernemingen zijn berekend inclusief een restwaarde - methode met een oneindige reeks kasstromen - doordat er sprake is van i) goodwill of ii) van kasstroomgenerende eenheden met meerdere activa. Dit is anders dan wanneer er sprake is van één actief met een bepaalbare levensduur in een kasstroomgenerende eenheid. In deze situatie kan in beginsel worden volstaan met een berekening van de bijzondere waardevermindering op basis van een eindige reeks kasstromen.

I4! Bron: Maddisson. Zie http://www.ggdc.net/ maddison/.

15 CAPM kent de volgende formule $E\left(R_{i}\right)=R_{f}$ $+\beta_{i}\left(E\left(R_{m}\right)-\left(R_{f}\right)\right.$. De leveraged bèta $\left(\beta_{i}\right)$ is gedownload van www.talanton.nl/nn//bèta. Deze bèta wordt maandelijks berekend op basis van een vijf jaar historisch rendement met een door Datastream gewogen index van de Nederlandse aandelenmarkt waarin alle sectoren vertegenwoordigd zijn. Vervolgens hebben we de unleveraged bèta berekend (Hamada proces, 1972) aan de hand van de volgende formule $\beta_{u}-\beta_{\llcorner} / 1+$ $(D / E) *(1-t)](D / E=b o o k$ value leverage ratio $\mathrm{t}=$ belastingdruk). We hebben gerekend met een risicovrij rendement $\left(R_{f}\right.$ zijnde de rente op tien jaar Nederlandse staatsobligaties en het historisch marktrendement Euronext Amsterdam over de afgelopen 25 jaar. Aan de hand van deze variabelen is met behulp van CAPM per onderneming een theoretische disconteringsvoet bepaald. In 2008 is de risico-opslag op staatsobligaties als gevolg van de crisis verder opgelopen. Bovendien is er voor euro-obligaties voor de diverse landen binnen de eurozone een creditspread ontstaan, wat een verdere risicodifferentiatie op landniveau aangeeft. Indien wij een risico-opslag hanteren op risicovrij rendement $\left(R_{f}\right)$ als gevolg van toegenomen risico-opslag voor staatsobligaties in 2008, dan zou dit de gevonden resultaten versterken: er zou dus sprake zijn van meer ondernemingen onder de bandbreedte (tabel 2, kolom 'disconteringsvoet', subkolom 'lager').

16 We hebben ook een 2-sided t-test uitgevoerd op gemiddelden. De t-test heeft een waarde van 40,35 en is significant op $1 \%$. Dit betekent dat de gemiddelden statistisch significant verschillend zijn van elkaar.

17 Afwaarderingen op vlottende activa (handelsvoorraden en handelsdebiteuren) geven een beeld van de verandering van de door het management verwachte winstgevendheid op korte termijn.

18 Mogelijk dat opportunisme hier een rol speelt doordat managers wel impliciet verwachte toekomstige rendementen willen communiceren door een toename van bijzondere waardeverminderingen, maar dit niet willen expliciteren in het directieverslag. Dit is vergelijkbaar met onderzoek (bijvoorbeeld Riedl en Srinivasan, 2009), dat beschrijift dat eenmalige lasten gepresenteerd in de winst-en-verliesrekening minder persistentie hebben dan eenmalige lasten in de toelichting. 19. Bron: http://www.cpb.nl/nl//research/sector1/ data/.

\section{Bijlage 1 Lijst van in het onderzoek betrokken ondernemingen}

$\begin{array}{llllll}\text { AALBERTS INDUSTR } & \text { BAM GROEP KON } & \text { FORNIX BIOSCIENCES } & \text { MACINTOSH RETAIL } & \text { PUNCH GRAPHIX } & \text { TELEGRAAF MEDIA GR } \\ \text { ACCELL GROUP } & \text { BATENBURG BEHEER } & \text { FUGRO } & \text { MANAGEMENT SHARE } & \text { QURIUS } & \text { TEN CATE } \\ \text { AHOLD KON } & \text { BE SEMICONDUCTOR } & \text { GALAPAGOS } & \text { MEDIQ } & \text { RANDSTAD } & \text { THUNDERBIRD } \\ \text { AIR FRANCE-KLM } & \text { BETER BED } & \text { GAMMA HOLDING } & \text { NEDAP } & \text { REED ELSEVIER } & \text { TIE HOLDING } \\ \text { AJAX } & \text { BLUE FOX ENTERPRSE } & \text { GRONTMIJ } & \text { NEDFIELD } & \text { ROOD TESTHOUSE } & \text { TKH GROUP } \\ \text { AKZO NOBEL } & \text { BOSKALIS WESTMIN } & \text { HEIJMANS } & \text { NEWAYS } & \text { ROTO SMEETS } & \text { TNT } \\ \text { ALANHERI } & \text { BRILL KON } & \text { HEINEKEN } & \text { ELECTRONICS } & \text { ROYAL DUTCH SHELLA } & \text { TOMTOM } \\ \text { AMG } & \text { BRUNEL INTERNAT } & \text { HES BEHEER } & \text { NUTRECO } & \text { ROYAL DUTCH SHELLB } & \text { UNILEVER } \\ \text { AMSTERDAM } & \text { CROWN VAN GELDER } & \text { HITT } & \text { NYLOPLAST } & \text { SAMAS NV } & \text { UNILEVER } \\ \text { COMMOD. } & \text { CRUCELL } & \text { HOLLAND COLOURS } & \text { OCE } & \text { SBM OFFSHORE } & \text { UNIT } 4 \text { AGRESSO } \\ \text { AMT HOLDING } & \text { CSM } & \text { HUNTER DOUGLAS } & \text { OCTOPLUS } & \text { SCHUITEMA } & \text { USG PEOPLE } \\ \text { AND INTERNATIONAL } & \text { CTAC } & \text { ICT AUTOMATISERING } & \text { NCOMETHYLOME } & \text { SIMAC TECHNIEK } & \text { VERIZON COMM. } \\ \text { ANTONOV } & \text { DOC DATA } & \text { IMTECH } & \text { SCNC } & \text { SLIGRO FOOD GROUP } & \text { VIVENDA MEDIA GR } \\ \text { ARCADIS } & \text { DPA FLEX GROUP } & \text { INNOCONCEPTS } & \text { ORANJEWOUD A } & \text { SMIT INTERNATIONAL } & \text { VOPAK } \\ \text { ARCELORMITTAL } & \text { DRAKA HOLDING } & \text { KENDRION } & \text { ORDINA } & \text { SOPHEON } & \text { WAVIN } \\ \text { ASM INTERNATIONAL } & \text { DSM KON } & \text { KPN KON } & \text { PHARMING GROUP } & \text { SPYKER CARS } & \text { WEGENER } \\ \text { ASML HOLDING } & \text { ERIKS GROEP } & \text { LBI INTERNATIONAL } & \text { PHILIPS KON } & \text { STERN GROEP } & \text { WESSANEN KON } \\ \text { BALLAST NEDAM } & \text { EXACT HOLDING } & \text { LOGICA } & \text { PORCELEYNE FLES } & \text { SUPER DE BOER } & \text { WOLTERS KLUWER }\end{array}$


Bijlage 2 Beschrijvende statistiek grootte van onderzochte ondernemingen

\begin{tabular}{|c|c|c|c|c|c|c|c|c|c|c|c|}
\hline \multirow{2}{*}{ Bedrijfstak } & \multirow{2}{*}{ N } & \multicolumn{2}{|c|}{ Balanstotaal } & \multicolumn{2}{|c|}{ Boekwaarde } & \multicolumn{2}{|c|}{ Omzet } & \multicolumn{2}{|c|}{ Winst } & \multicolumn{2}{|c|}{ Personeel } \\
\hline & & GEM & STDEV & GEM & STDEV & GEM & STDEV & GEM & STDEV & GEM & STDEV \\
\hline 0100 Grondstoffen & 2 & 106.572 & 178.990 & 43.080 & 72.923 & 66.070 & 109.922 & 6.131 & 10.243 & 39.748 & 54.144 \\
\hline 1000 Basismaterialen & 5 & 32.328 & 56.858 & 9.999 & 15.854 & 29.974 & 53.481 & 1.269 & 3.188 & 21.472 & 24.910 \\
\hline 2000 Industrie & 34 & 1.465 & 2.015 & 414 & 574 & 2.036 & 3.234 & 56 & 111 & 10.845 & 28.383 \\
\hline 3000 Consumentengoederen & 16 & 5.488 & 10.331 & 2.213 & 4.559 & 6.302 & 11.924 & 346 & 1.298 & 26.879 & 52.885 \\
\hline 4000 Gezondheidszorg & 6 & 159 & 236 & 106 & 173 & 66 & 103 & -2 & 13 & 338 & 415 \\
\hline 5000 Consumentenservices & 17 & 4.115 & 7.864 & 1.299 & 2.720 & 4.506 & 8.082 & 65 & 400 & 13.005 & 26.600 \\
\hline 6000 Telecom & 1 & 23.913 & - & 3.730 & - & 14.427 & - & 1.332 & - & 36.702 & - \\
\hline 9000 Technologie & 18 & 919 & 1.418 & 524 & 1.042 & 766 & 1.257 & -28 & 213 & 5.088 & 9.853 \\
\hline Totaal/Gemiddelde & 99 & 7.284 & 34.260 & 2.643 & 13.392 & 6.182 & 23.479 & 339 & 1.997 & 13.498 & 30.977 \\
\hline
\end{tabular}

Bijlage 3 Overzicht gerealiseerde resultaten (paragraaf 3.3)

\begin{tabular}{|c|c|c|c|c|c|c|c|c|c|c|}
\hline \multirow[t]{2}{*}{ Bedriffstak } & \multicolumn{2}{|c|}{ Kasstroom } & \multicolumn{2}{|c|}{ Brutomarge } & \multicolumn{2}{|c|}{$\begin{array}{l}\text { EBITDA } \\
\text { Omzet }\end{array}$} & \multicolumn{2}{|c|}{$\begin{array}{l}\text { Voorziening } \\
\text { voorraden }\end{array}$} & \multicolumn{2}{|c|}{$\begin{array}{l}\text { Voorziening } \\
\text { debiteuren }\end{array}$} \\
\hline & 2008 & 2007-2005 & 2008 & 2007-2005 & 2008 & 2007-2005 & 2008 & 2007-2005 & 2008 & 2007-2005 \\
\hline 0100 Grondstoffen & $13,4 \%$ & $14,3 \%$ & $44,4 \%$ & $48,0 \%$ & $21,0 \%$ & $23,0 \%$ & $0,1 \%$ & $0,3 \%$ & $4,5 \%$ & $3,3 \%$ \\
\hline 1000 Basismaterialen & $0,0 \%$ & $6,1 \%$ & $35,8 \%$ & $37,6 \%$ & $8,3 \%$ & $12,0 \%$ & $2,6 \%$ & $3,0 \%$ & $3,2 \%$ & $2,8 \%$ \\
\hline 2000 Industrie & $7,1 \%$ & $7,6 \%$ & $41,0 \%$ & $44,0 \%$ & $11,2 \%$ & $11,6 \%$ & $5,5 \%$ & $4,4 \%$ & $5,5 \%$ & $4,6 \%$ \\
\hline 3000 Consumentengoederen & $4,8 \%$ & $6,5 \%$ & $34,4 \%$ & $40,9 \%$ & $8,1 \%$ & $9,6 \%$ & $7,1 \%$ & $4,4 \%$ & $5,1 \%$ & $4,0 \%$ \\
\hline 4000 Gezondheidszorg & $-12,9 \%$ & $-52,2 \%$ & $68,6 \%$ & $66,7 \%$ & $-3,0 \%$ & $-39,4 \%$ & $7,0 \%$ & $5,5 \%$ & $4,3 \%$ & $5,1 \%$ \\
\hline 5000 Consumentenservices & $2,1 \%$ & $7,7 \%$ & $54,7 \%$ & $47,9 \%$ & $7,7 \%$ & $12,7 \%$ & $4,5 \%$ & $3,7 \%$ & $10,4 \%$ & $9,8 \%$ \\
\hline 6000 Telecom & $17,0 \%$ & $19,0 \%$ & $56,5 \%$ & $56,7 \%$ & $34,0 \%$ & $39,3 \%$ & $31,4 \%$ & $56,7 \%$ & $9,8 \%$ & $10,8 \%$ \\
\hline 9000 Technologie & $2,8 \%$ & $17,9 \%$ & $65,3 \%$ & $64,4 \%$ & $11,7 \%$ & $23,3 \%$ & $5,8 \%$ & $4,2 \%$ & $6,2 \%$ & $5,9 \%$ \\
\hline Gemiddeld & $4,7 \%$ & $7,8 \%$ & $46,6 \%$ & $47,7 \%$ & $10,3 \%$ & $12,8 \%$ & $5,7 \%$ & $4,8 \%$ & $6,2 \%$ & $5,5 \%$ \\
\hline \multicolumn{11}{|c|}{$\begin{array}{l}\text { Kasstroom / Omzet = de nettokasstroom voor een periode gedeeld door de omzet voor dezelfde periode. } \\
\text { Brutomarge }=\text { omzet minus kostprijs omzet gedeeld door omzet. } \\
\text { EBITDA = resultaat voor rente, vennootschapsbelasting en afschrijingen gedeeld door omzet. } \\
\text { Voorziening voorraden = omvang van de voorziening voor kostprijs/lagere marktwaarde en incourantheid gedeeld door de totale voorraadwaarde. } \\
\text { Voorziening debiteuren = de hoogte van de voorziening voor oninbaarheid gedeeld door de omvang van de totale debiteurenportefeuille. }\end{array}$} \\
\hline
\end{tabular}

